\title{
Morphometry and Sexual Dimorphism of the Human Clavicle in South Indian Population
}

Praveen Kumar Panuganti ${ }^{1}$, Muchintala Venkateshwar Reddy ${ }^{2}$, Meghana S Poojari ${ }^{3}$, Patil Shrish ${ }^{4}$, Jyothi Ashok Kumar *5.

${ }^{1}$ Assistant Professor, Department of Anatomy, SVS Medical College, Mahaboob Nagar, Telangana, India.

${ }^{2}$ Professor \& Head, Department of anatomy, SVS Medical College, Mahaboob Nagar, Telangana, India.

${ }^{3}$ Tutor, Department of Anatomy, Basaveshwara Medical College and Hospital, Chitradurga, Karnataka, India.

${ }^{4}$ Professor \& Head, Department of Anatomy,Basaveshwara Medical College and Hospital, Chitradurga, Karnataka, India.

${ }^{*}$ Assistant Professor, Department of Anatomy, Basaveshwara Medical College and Hospital, Chitradurga, Karnataka. India.

\section{ABSTRACT}

Background: In forensic anthropology, determining an individual's sex is the fundamental criteria of identification, but this is a tough task that gets considerably more difficult when only a single bone, such as the clavicle, is available. In physical anthropology, determining the sex of a deceased individual is a fundamental prerequisite. Physical anthropologists have gotten more concerned about the difficulties of human identity in recent years. Traditional techniques of sexing bone are subjective and ineffective when absolute sexing precision is desired, hence this study.

Methods: Measurement of clavicular length and circumference using an Osteometric board or sliding and Vernier Callipers product from 1128 dry clavicles of unknown sex and age procured from various medical institutions and departments of anthropology in south India. Length, inner angle, outer angle, the sum of angles, inner segment, middle segment, outside segment, width at the inner end at an inner angle, least width at conoid tubercle, at the outer end, and mid circumference have all been measured.

Results and Discussion: The male mid-shaft circumference is $38.0 \pm 0.5 \mathrm{~mm}$ on the right side and $36.5 \pm 0.5 \mathrm{~mm}$ on the left side, whereas the female mid-shaft circumference is $31.4 \pm 0.3 \mathrm{~mm}$ on the right side and $31.4 \pm 0.6 \mathrm{~mm}$ on the left side. The length of the left clavicle is greater than the length of the right collarbone. The curvature of the right collarbone is higher than that of the left, resulting in a shorter right bone than the left. The clavicle of males has a higher mean across all parameters than females. Male clavicle length is more than female clavicle length, midshaft circumference is less in females than males, and breadth at an inner angle is shorter in females than men, all of which are statistically significant. The Mid-shaft Circumference as a sex-determination metric is statistically significant in differentiating the clavicle's sex. This delivers a better result than clavicle weight since clavicle weight fluctuates with age and the health state of the individual. Male clavicles have a larger Midshaft Circumference than female clavicles.

KEY WORDS: Anthrozoology, Clavicle, Morphometry, Skeletal Remains, Mid-Shaft Circumference.

Corresponding Author: Dr. Jyothi Ashok Kumar, Assistant Professor, Department of Anatomy, Basaveshwara Medical College and hospital, Chitradurga, Karnataka, India.

E-Mail: jyothiashok.anatomist@gmail.com

Access this Article online

Quick Response code

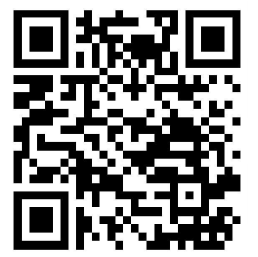

DOI: $10.16965 /$ ijar.2021.205

Journal Information

International Journal of Anatomy and Research

ISSN (E) 2321-4287 | ISSN (P) 2321-8967

https://www.ijmhr.org/ijar.htm

DOI-Prefix: https://dx.doi.org/10.16965/ijar

Article Information

Received: 15 Dec 2021

Peer Review: 16 Dec 2021

Revised: 23 Dec 2021
Accepted: 19 Jan 2022

Published (O): 05 Mar 2022

Published (P): 05 Mar 2022 


\section{INTRODUCTION}

The determination of the sex is a crucial stage in the process of identification of an unknown individual from skeletal remains. In physical anthropology, determining the sex of a deceased individual correctly is a crucial necessity. While determining the person's age, sex, height, and race are the major criteria for identification (bog fours). The adult clavicles were chosen for the investigation because the evident sex differences appear only after puberty. When a whole skeleton is available for inspection, determining the sex is not difficult. Precision in sex determination of sex of skeleton is based on the number of bones available [1].

Although DNA analysis has been helpful in identifying unknown victims, it is of limited use when there are no family members who can positively identify or claim the deceased $[2,3]$ In India, forensic pathologists frequently come across situations where traditional methods of identification, such as fingerprints, DNA, and antemortem dental records, are of little or no use. In these cases, forensic personnel routinely contact anatomists for their expert opinion on human identity in terms of sex, age, size, race, and likely cause of death for medico-legal considerations. Their conclusion is based on an examination of such skeletal remains [4].

The human clavicle is only a long bone present horizontally in the body, it has two ends and an intervening shaft. The shaft is gradually curved with convexity in the medial two-third, and concavity at the lateral one-third. The clavicle is heavier and has a more curved profile in manual workers, and the ridges that define the attachment sites for muscle tissue are more obvious $[5,6]$. Most (over $80 \%$ ) clavicle fractures occur at the junction of two curvatures. In Primates, the shoulder complex has three bones known as the scapula, clavicle, and humerus, as well as around 20 muscles, but this number might vary based on the species. The presence of four joints adds to the complexity. The clavicle, in comparison to the humerus and scapula, has received less attention.
Despite the fact that numerous workers studied the morphometry data of the clavicles in different regions of the world, the existing data evidently exhibits that there is pinching of metrical data of the clavicle. As a result, the current study aims to investigate the sex difference in different measurements of human clavicles of known sex. Even for plate applications during surgeries, attention to the length and curvature is required, whereas, for intramedullary nail applications, width and diameter are important. The goal of such a study was to investigate length, width, angled, and circumference. It can study the main distinctions between clavicle geometries on the right and left.

\section{MATERIALS AND METHODS}

1128 clavicles were gathered from the medical institutions and anthropology departments. Based on basic anatomical differentiating features separated male and female clavicle [males 564 (282 Rt. \& 282 Lt.) females (282 Rt. \& 282 Lt.)]. Length, inner angle, outer angle, the sum of angles, inner segment, middle segment, outer segment, width at the inner end, at an inner angle, at conoid tubercle, at the outer end, and midshaft circumference were measured using a protractor, an Osteometric board or sliding, and Vernier Calipers.

The bone was positioned on a lump of plasticine so that its anterior and posterior margins were in the same horizontal plane. A dioptograph was used to trace the outline of the bone as seen from above on a sheet of paper. The midpoints at the sternal and acromial ends of a clavicle were acquired and indicated as points ' $a$ ' and ' $b$ ' met by a straight line on the contour of a clavicle. The bone's axis was drawn as a curving line halfway between the anterior and posterior borders along the length of the clavicle. The medial third of this curving line was convex anteriorly, whereas the lateral third was convex posteriorly. The deepest points on two curves of the bones where convexities were greatest are denoted by the letters ' $c$ ' and ' $d$ ' connected by a straight line. Finally, these locations are connected with midpoints ' $a$ ' and 
' $b$ ' at the endpoints of lines $c a$ and $d b$. As a result, two angles are formed: an inner or medial angle a, $c, d$ with a curvature of $2 / 3 r d s$, and an outer or lateral angle $c, d, b$ with $a$ curvature of $1 / 3$ rd. A protractor is used to measure these angles were seen in figure 1 and table 1 . The total curvature of the bone was calculated by adding the two angles. All measurements were taken by using Vernier caliper, sliding caliper, and protractor.
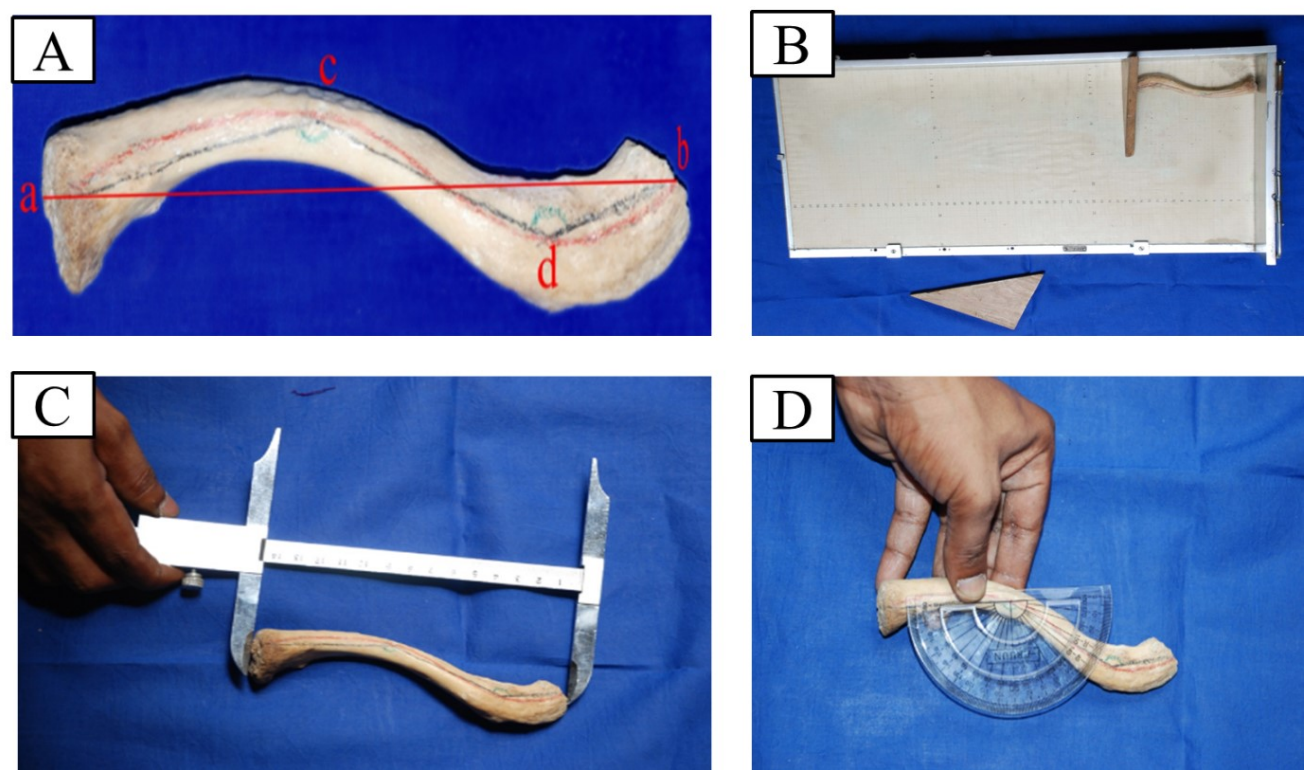

Fig. 1: Human Clavicle morphometry. A: Contour of the right clavicle (a-Midpoint of sternal end, b-Midpoint of the acromial end, c-Deepest point of medial curvature, d-Deepest point of lateral curvature, a $c d-$ Medial angle and $\mathrm{c} \mathrm{d} \mathrm{b}$ - Lateral angle; B: Measuring the length of the clavicle with the help of Osteometric board; C: Measuring the length of the clavicle with the help of sliding caliper; D: Measuring the inner angle of the clavicle with the help of a protractor.

\section{RESULTS}
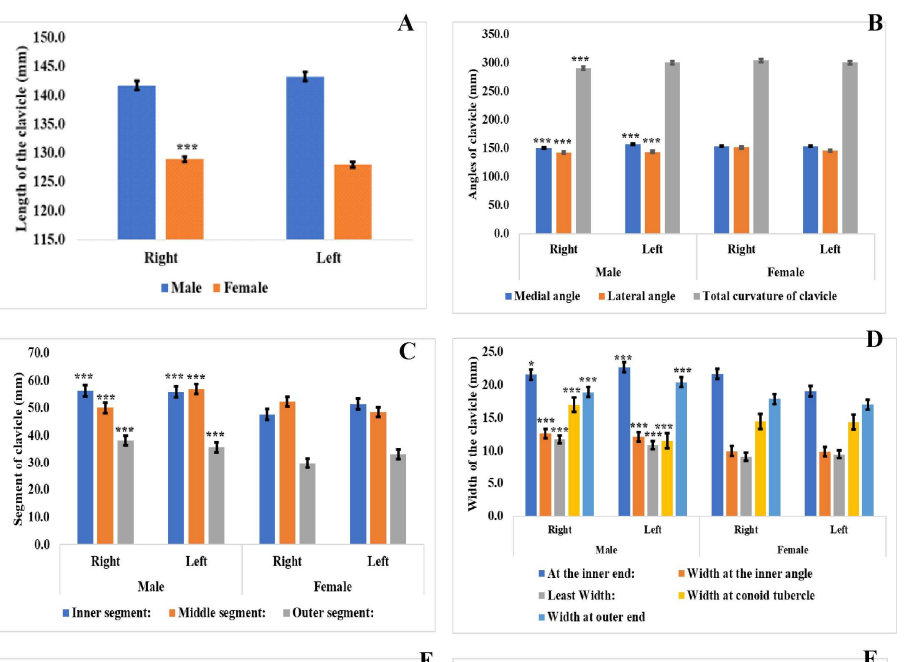

Fig. 2: Morphometric measurements of the human clavicle. A: Length of the clavicle; B: Angles of the clavicle; C: Segments of the clavicle; D: Widths of the clavicle; E: Depths of the clavicle; F: Midshaft circumference of the clavicle. ('***' denotes $p$ value $<0.0001$, '*' denotes $p$ value $<0.05$ and ' $N S^{\prime}$ ' denotes nonsignificant).
Statistical analysis: The data were evaluated by using SPSS software (IBM, USA, ver. 21). The results were expressed as the Mean \pm Standard error (S.E). A value of $p<0.05$ was considered significant.

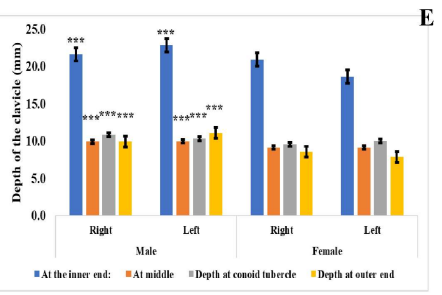

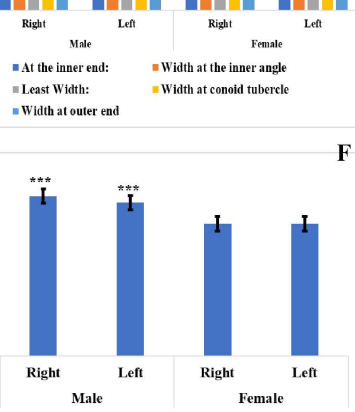



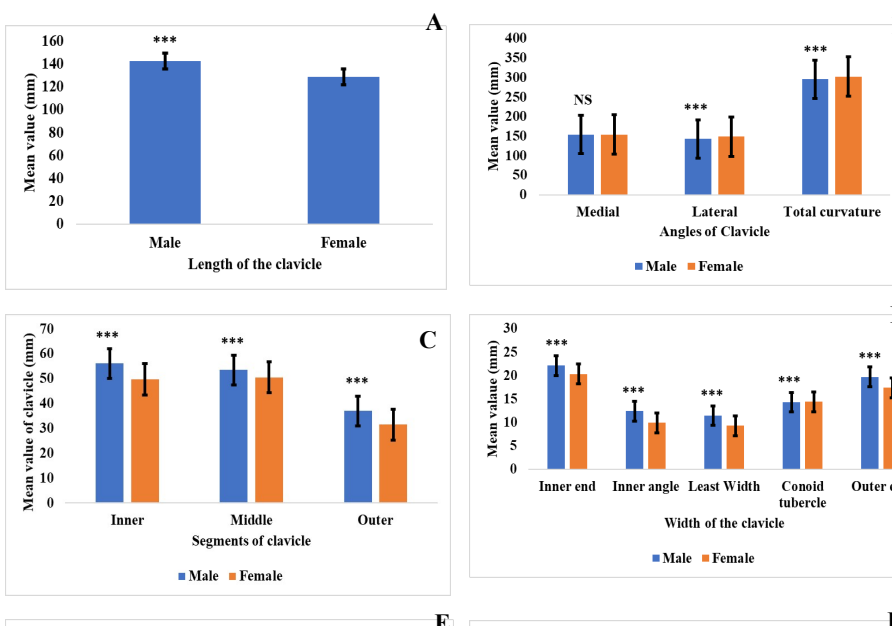

D

Fig. 3: Comparison of morphometric measurements of human clavicle between male and female. A: Length of the clavicle; B: Angles of the clavicle; C: Segments of the clavicle; D: Widths of the clavicle; E: Depths of the clavicle; F: Midshaft circumference of the clavicle. ('***' denotes $p$ value $<0.0001{ }^{\prime}{ }^{\prime *}$ ' denotes $p$ value $<0.05$ and ' $N S^{\prime}$ ' denotes nonsignificant).
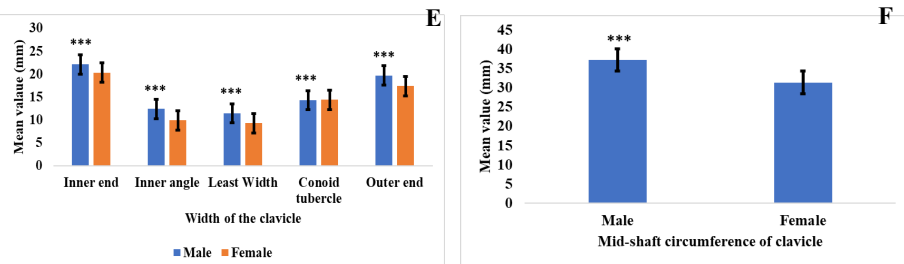

Widths of the clavicle; E: Depths of the clavicle; F: Midshaft circumference of the clavicle. ('***' denotes $\mathrm{p}$ value $<0.0001,{ }^{\prime * \prime}$ denotes $\mathrm{p}$ value $<0.05$ and ' $\mathrm{NS}$ ' denotes non-significant).

\begin{tabular}{|c|c|c|c|c|c|c|}
\hline \multirow{2}{*}{ Measurements } & \multicolumn{2}{|l|}{$\begin{array}{c}\text { Male } \\
\text { (Mean } \pm \text { SE) }\end{array}$} & Total & \multicolumn{2}{|l|}{$\begin{array}{c}\text { Female } \\
(\text { Mean } \pm S E)\end{array}$} & \multirow{2}{*}{$\begin{array}{c}\text { Total } \\
\text { (Mean } \pm \text { SE) }\end{array}$} \\
\hline & Right & Left & (Mean \pm SE) & Right & Left & \\
\hline No. of bones & 282 & 282 & 564 & 282 & 282 & 564 \\
\hline Length & $141.7 \pm 0.1$ & $143.2 \pm 0.1$ & $142.5 \pm 1.1$ & $128.9 \pm 0.1$ & $128.0 \pm 0.1$ & $128.5 \pm 0.6$ \\
\hline$p$-value & \multicolumn{3}{|c|}{$0.0001^{* * *}$} & \multicolumn{3}{|c|}{$0.0001^{* * *}$} \\
\hline \multicolumn{7}{|l|}{ Angles } \\
\hline Medial & $151.0 \pm 0.0$ & $157.0 \pm 0.0$ & $154 \pm 4.2$ & $154 \pm 0.1$ & $154.0 \pm 0.0$ & $154 \pm 0.0$ \\
\hline$p$-value & \multicolumn{3}{|c|}{$0.0001^{* * *}$} & \multicolumn{3}{|c|}{$0.0001^{* * *}$} \\
\hline Lateral & $142.4 \pm 0.0$ & $143.7 \pm 0.1$ & $143.05 \pm 0.9$ & $151.3 \pm 0.1$ & $145.9 \pm 0.1$ & $148.6 \pm 3.8$ \\
\hline$p$-value & \multicolumn{3}{|c|}{$0.0001^{* * *}$} & \multicolumn{3}{|c|}{$0.0001^{* * *}$} \\
\hline Total curvature & $290.8 \pm 0.0$ & $300.4 \pm 0.1$ & $295.6 \pm 6.8$ & $304.3 \pm 0.1$ & $300.4 \pm 0.1$ & $302.4 \pm 2.8$ \\
\hline$p$-value & \multicolumn{3}{|c|}{$0.0001^{* * *}$} & \multicolumn{3}{|c|}{$0.9036^{\mathrm{NS}}$} \\
\hline \multicolumn{7}{|l|}{ Segments } \\
\hline Inner & $56.3 \pm 0.0$ & $55.8 \pm 0.0$ & $56.1 \pm 0.4$ & $47.8 \pm 0.0$ & $51.5 \pm 0.0$ & $49.7 \pm 2.6$ \\
\hline$p$-value & $0.0001^{* * *}$ & & & $0.0001^{* * *}$ & & \\
\hline Middle & $50.1 \pm 0.1$ & $56.9 \pm 0.1$ & $53.5 \pm 4.8$ & $52.4 \pm 0.1$ & $48.6 \pm 0.0$ & $50.5 \pm 2.7$ \\
\hline$p$-value & $0.0001^{* * *}$ & & & $0.0001^{* * *}$ & & \\
\hline Outer & $38.2 \pm 0.0$ & $35.7 \pm 0.0$ & $37.0 \pm 1.8$ & $29.8 \pm 0.1$ & $33.1 \pm 0.0$ & $31.45 \pm 2.3$ \\
\hline$p$-value & \multicolumn{3}{|c|}{$0.0001^{* * *}$} & \multicolumn{3}{|c|}{$0.0001^{* * *}$} \\
\hline \multicolumn{7}{|l|}{ Widths } \\
\hline Inner end & $21.5 \pm 0.0$ & $22.7 \pm 0.0$ & $22.1 \pm 0.8$ & $21.6 \pm 0.0$ & $19.0 \pm 0.1$ & $20.3 \pm 1.8$ \\
\hline p-value & $0.0375^{*}$ & & & $0.0001^{* * *}$ & & \\
\hline Inner angle & $12.6 \pm 0.0$ & $12.1 \pm 0.0$ & $12.4 \pm 0.4$ & $10 \pm 0.0$ & $9.8 \pm 0.0$ & $9.9 \pm 0.1$ \\
\hline$p$-value & $0.0001^{* * *}$ & & & $0.0001^{* * *}$ & & \\
\hline Least Width & $11.8 \pm 0.0$ & $10.9 \pm 0.0$ & $11.45 \pm 0.6$ & $9.1 \pm 0.0$ & $9.5 \pm 0.0$ & $9.3 \pm 0.3$ \\
\hline$p$-value & $0.0001^{* * *}$ & & & $0.0001^{* * *}$ & & \\
\hline Conoid tubercle & $17 \pm 0.0$ & $11.5 \pm 0.0$ & $14.3 \pm 3.9$ & $14.4 \pm 0.1$ & $14.4 \pm 0.0$ & $14.4 \pm 0.0$ \\
\hline$p$-value & $0.0001^{* * *}$ & & & $0.0001^{* * *}$ & & \\
\hline Outer end & $18.9 \pm 0.0$ & $20.4 \pm 0.0$ & $19.7 \pm 1.1$ & $17.8 \pm 0.0$ & $17.0 \pm 0.1$ & $17.4 \pm 0.6$ \\
\hline$p$-value & \multicolumn{3}{|c|}{$0.0001^{* * *}$} & \multicolumn{3}{|c|}{$0.0001^{* * *}$} \\
\hline \multicolumn{7}{|l|}{ Depths } \\
\hline Inner end & $21.7 \pm 2.2$ & $22.9 \pm 1.0$ & $22.3 \pm 0.8$ & $21.0 \pm 1.0$ & $18.7 \pm 2.4$ & $19.9 \pm 1.6$ \\
\hline p-value & $0.0001^{* * *}$ & & & $0.0001^{* * *}$ & & \\
\hline Middle & $9.9 \pm 5.3$ & $10 \pm 5.2$ & $9.95 \pm 0.1$ & $9.1 \pm 7.4$ & $9.2 \pm 5.0$ & $9.15 \pm 0.1$ \\
\hline$p$-value & $0.0001^{* * *}$ & & & $0.0001^{* * *}$ & & \\
\hline Conoid tubercle & $10.9 \pm 5.8$ & $10.3 \pm 5.2$ & $10.6 \pm 0.4$ & $9.6 \pm 3.3$ & $10.1 \pm 4.4$ & $9.85 \pm 0.4$ \\
\hline p-value & $0.0001^{* * *}$ & & & $0.0001^{* * *}$ & & \\
\hline Outer end & $10.0 \pm 3.8$ & $11.1 \pm 1.9$ & $10.6 \pm 0.8$ & $8.6 \pm 3.6$ & $7.9 \pm 3.4$ & $8.25 \pm 0.5$ \\
\hline$p$-value & \multicolumn{3}{|c|}{$0.0001 * * *$} & \multicolumn{3}{|c|}{$0.0001 * * *$} \\
\hline \multicolumn{7}{|l|}{ Circumference } \\
\hline Mid shaft & 38 & 36.5 & $37.25 \pm 1.1$ & 31.4 & 31.4 & $31.4 \pm 0.0$ \\
\hline$p$-value & \multicolumn{3}{|c|}{$0.0001^{* * *}$} & & $0.0001^{* * *}$ & \\
\hline
\end{tabular}

Table 1: Morphometry measurements of human clavicles. 
Table 2: Comparison of morphometric measurements of human clavicle between male and female.

\begin{tabular}{|c|c|c|c|}
\hline Measurements & $\begin{array}{c}\text { Male } \\
\text { (Mean } \pm \text { SE) }\end{array}$ & $\begin{array}{c}\text { Female } \\
\text { (Mean } \pm S E)\end{array}$ & p-value \\
\hline No. of bones & 564 & 564 & \multirow{2}{*}{0.0001} \\
\hline Length & $142.5 \pm 1.6$ & $128.5 \pm 1.5$ & \\
\hline \multicolumn{4}{|l|}{ Angles } \\
\hline Medial & $154 \pm 1.1$ & $154 \pm 0.5$ & 1 \\
\hline Lateral & $143.1 \pm 1.4$ & $148.6 \pm 1.4$ & 0.0001 \\
\hline Total curvature & $295.6 \pm 0.0$ & $302.4 \pm 0.0$ & 0.0001 \\
\hline \multicolumn{4}{|l|}{ Segments } \\
\hline Inner & $56.1 \pm 0.0$ & $49.6 \pm 0.0$ & 0.0001 \\
\hline Middle & $53.5 \pm 0.0$ & $50.5 \pm 0.0$ & 0.0001 \\
\hline Outer & $37.0 \pm 0.0$ & $31.5 \pm 0.0$ & 0.0001 \\
\hline \multicolumn{4}{|l|}{ Widths } \\
\hline Inner end & $22.1 \pm 0.0$ & $20.3 \pm 0.1$ & 0.0001 \\
\hline Inner angle & $12.4 \pm 0.0$ & $9.9 \pm 0.0$ & 0.0001 \\
\hline Least Width & $11.3 \pm 0.0$ & $9.3 \pm 0.0$ & 0.0001 \\
\hline Conoid tubercle & $14.3 \pm 0.1$ & $14.4 \pm 0.0$ & 0.0001 \\
\hline Outer end & $19.7 \pm 0.0$ & $17.4 \pm 0.1$ & 0.0001 \\
\hline \multicolumn{4}{|l|}{ Depths } \\
\hline Inner end & $22.3 \pm 0.0$ & $19.8 \pm 0.0$ & 0.0001 \\
\hline Middle & $10.0 \pm 0.0$ & $9.2 \pm 0.0$ & 0.0001 \\
\hline Conoid tubercle & $10.6 \pm 0.0$ & $9.9 \pm 0.0$ & 0.0001 \\
\hline Outer end & $10.5 \pm 0.0$ & $8.2 \pm 0.0$ & 0.0001 \\
\hline \multicolumn{4}{|l|}{ Circumference } \\
\hline Mid shaft & $37.3 \pm 0.0$ & $31.4 \pm 0.0$ & 0.0001 \\
\hline
\end{tabular}

Length of the clavicle: Although there are statistically significant relationships between sex and collarbone length ( $p$-value $=0.0001$ ), the length in male clavicles $(R=141.7 \pm 0.1$ and $\mathrm{L}=143.2 \pm 0.1$ ) was higher than the female clavicles ( $R=128.9 \pm 0.1$ and $L=128.0 \pm 0.1)$ on either side (Table 1 , figure $2 \mathrm{~A}$ ).

Angles of clavicle: The average medial and lateral angles of the right clavicle was 151.0 \pm 0.0 and $142.4 \pm 0.0$ in males, while in the female was $154 \pm 0.1$ and $151.3 \pm 0.1$, whereas the left male and female clavicle was recorded to be $157.0 \pm 0.0,143.7 \pm 0.1$ and $154.0 \pm 0.0,145.9 \pm 0.1$, respectively (Table I). Although the difference between the male and female clavicle was recorded, a highly significant correlation was found between the medial and lateral angle of the clavicle $(p$-value $=0.0001)$ (Table 1 , figure 2B ).

Mid-shaft circumference of the clavicle: The perimeter of the mid-shaft of the right and left male clavicle was more than their female clavicle, with a mean mid-shaft perimeter of $37.3 \mathrm{~mm}$ and $31.4 \mathrm{~mm}$ in males and females, respectively (Table 1 , figure $2 \mathrm{~F}$ ). The mid-shaft perimeter was statistically significant in sex determination ( $p$-value $=0.0001$ ).

\section{Segments, depth, and width of the clavicle:}

Gender-specific highly significant statistical analysis (' $p$ ' $<0.001$ ) was found to exist in the case of segment, depth, and width of the clavicle. Side-specific significant statistical analysis was also found in male clavicles $(p<0.0001)$ for all parameters as well as in females. In general, the values of segment, depth, and width of clavicle were found to be higher for males than for females. Table 2 shows in all metrics, the male has a higher mean value than the female.

\section{DISCUSSION}

The human clavicle has a greater degree of variations (Grant, 1971) among people of various ages, sexes, races, and occupations [7-11]. Clinical treatments [8-12] and forensic anthropological identifications [7,13-23] have both benefited from the anatomical knowledge of the diversity of the clavicle. Moreover, the clavicle's anatomical and biomechanical features impact the design of clavicle fixative devices. The use of pre-designed devices for the stabilization of collarbone fractures may be limited in clinical practice due to a lack of awareness of such differences. Clinicians are required to have a thorough understanding of the bone's pre-fracture anatomical structure and function, but they are not expected to be experts in population-specific variances in these characteristics. In a forensic context, differences in clavicular osteological features may be used to identify an unknown skeleton. The clavicle's mid-shaft circumference has been measured in multiple races by various researchers, and it is the most often used clavicular metric for sex identification. Oliver $\mathrm{G}[16,24-39]$ has compiled a table that summarises the findings of numerous researchers in this area.

Furthermore, determining a person's sex using human skeletal remains is an essential part of forensic identification and the beginning point for anthropological study. The clavicle bone measurements were analyzed in this study. Men have larger clavicle bones than 
Praveen Kumar Panuganti, et al., Morphometry and Sexual Dimorphism of the Human Clavicle in South Indian Population.

Table 3: Comparison of mid-shaft circumference of male \& female clavicles by different authors.

\begin{tabular}{|c|c|c|c|c|c|c|c|c|c|}
\hline \multirow{2}{*}{ SI. No. } & \multirow{2}{*}{ Year } & \multirow{2}{*}{ Author } & \multirow{2}{*}{ Region } & \multirow{2}{*}{ Side } & \multicolumn{2}{|c|}{ Male } & \multicolumn{2}{|c|}{ Female } & \multirow{2}{*}{ P-value } \\
\hline & & & & & Mean & Range & Mean & Range & \\
\hline \multirow{2}{*}{1} & \multirow{2}{*}{1932} & \multirow{2}{*}{ Terry RJ [9] } & \multirow{2}{*}{ USA Negroes } & Rt & 40.02 & - & 35.26 & - & \multirow{2}{*}{$<0.001$} \\
\hline & & & & Lt & 38.58 & - & 32.42 & - & \\
\hline \multirow{2}{*}{2} & \multirow{2}{*}{1932} & \multirow{2}{*}{ Terry RJ [9] } & \multirow{2}{*}{ USA whites } & Rt & 40.02 & - & 35.16 & - & \\
\hline & & & & $\mathrm{Lt}$ & 40.06 & - & 38.42 & - & \\
\hline \multirow{2}{*}{3} & \multirow{2}{*}{1951} & \multirow{2}{*}{ Oliver G [23] } & \multirow{2}{*}{ French (France) } & Rt. & 38.4 & - & 31.06 & - & \\
\hline & & & & Lt. & 38.4 & - & 31.6 & - & \\
\hline \multirow{2}{*}{4} & \multirow{2}{*}{1963} & Doengen RY [241 & Auctralia & Rt & 36.2 & - & 29.5 & - & $<0001$ \\
\hline & & Doengen Kv [24] & Austidild & Lt & 36.2 & - & 29.5 & - & $<0.001$ \\
\hline 5 & 1966 & lit \& \& Singh S [15] & Amritsar 7one & Rt & 36.17 & $27.11-45.23$ & 29.69 & 24.47-34.91 & $<0001$ \\
\hline J & 1900 & ] & Amintsal zunte & $\mathrm{Lt}$ & 35.7 & $26.22-45.18$ & 29.51 & $23.60-35.42$ & 20.001 \\
\hline 6 & 1068 & Singh S \& Gangrade KC & Varanaci Zone & Rt & 35.09 & $25-28$ & 28.52 & 21-41 & 00001 \\
\hline 6 & 1968 & Singn ১ \& Gangrade KC [< ] & Varanasi Zone & Lt & 34.64 & $25.12-44.16$ & 28 & $21.32-34.68$ & \\
\hline 7 & 1069 & Singh C [26] & Amorican Nearoes & Rt & 39.96 & - & 33.06 & - & OPOQ⿻1 \\
\hline / & 1969 & Singn $S$ [26] & American INegroes & $\mathrm{Lt}$ & 39.08 & - & 32.66 & - & 0.0001 \\
\hline 8 & 1969 & Singh S [26] & American whites & Rt & 38.47 & - & 31.61 & - & 00001 \\
\hline 8 & 1909 & Singn $S[20]$ & American writes & Lt & 37.61 & - & 30.72 & - & 0.0001 \\
\hline 0 & 1092 & lit \& Sahni [ [27] & Chandiaarh 7ono & Rt & 36.2 & $31-45$ & 30.4 & $24.0-35.0$ & $<0001$ \\
\hline 9 & 1983 & Jit I S Sanni D [2/] & Cnanaigam zome & Lt & 35.9 & $27.8-45$ & 30 & $21.6-38.0$ & $<0.001$ \\
\hline 10 & 1992 & Caven P ot al [28] & Bangalore zone & Rt & 37 & - & 32 & - & $<0001$ \\
\hline 10 & 1992 & Sayee R et al [28] & Bangalore zone & $\mathrm{Lt}$ & 37 & - & 35 & - & $<0.001$ \\
\hline 11 & 2009 & Padevannanavar et al [201 & North \& Interior Karnataka & Rt & 38.34 & $30.0-54.0$ & 31.76 & $24.0-37.0$ & $<0.001$ \\
\hline 11 & 2007 & 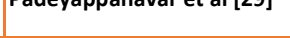 & 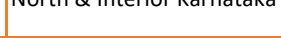 & Lt & 37.96 & $28.0-45.0$ & 32.44 & $25.0-39.0$ & \\
\hline 12 & 2011 & Homen al ras & Nenoloce Donulation & Rt & 37.14 & $30.0-46.0$ & 30.5 & $25.5-41.5$ & Oח001 \\
\hline & & Haque et al [Jo] & Trepalese rupuiationt & Lt & 37 & $30.0-48.0$ & 30.3 & $24.5-39.5$ & 0.001 \\
\hline 14 & 2014 & Kralik et al [21] & Modern Greek & Rt & 41.18 & - & 34.79 & - & 00001 \\
\hline 14 & 2014 & Krallk et al [31] & IVIodern Greek & Lt & 40.37 & - & 34.31 & - & 0.0001 \\
\hline 15 & 2015 & Alicina ot a [32] & Snanish & Rt & 38 & - & 31.36 & - & 00001 \\
\hline 15 & 2015 & Alicina et al [32] & Spanisn & Lt & 37.26 & - & 30.3 & - & 0.0001 \\
\hline 16 & 2016 & Ishwarkumar et al [33] & Kuazulu-Natal Ponulation & Rt & 38.6 & - & 38.68 & - & 0004 \\
\hline & & & & Lt & 33.58 & - & 34.93 & - & \\
\hline 17 & 2016 & Daiitha ot & Tamilnadunonulation & Rt & 38.34 & - & 34.35 & - & 0.0004 \\
\hline 17 & 2010 & hajitind EL. Ai[34] & Idmintadu populdtion & Lt & 39.48 & - & 33.68 & - & 0.0001 \\
\hline 18 & 2016 & Sehrawat \& Pathak [35] & _- & Rt & 38.52 & & 32.66 & & 0.0001 \\
\hline & & & & Lt & 37.24 & & 31.76 & & \\
\hline 19 & 2019 & Shoba et al [36] & North Karnataka & Rt & 37.14 & - & 30.5 & - & 0.0001 \\
\hline & & & population & Lt & 37.04 & - & 30.3 & - & \\
\hline 20 & 2010 & Rohiva ot a [27] & D & Rt & 37.95 & - & 32.14 & - & 00001 \\
\hline 20 & 2019 & Dehiya et al [37] & - & $\mathrm{Lt}$ & 36.59 & - & 29.74 & - & 0.0001 \\
\hline 21 & 2021 & Drecent ctudv & South India nonulation & Rt & 38 & - & 31.4 & - & 0001 \\
\hline & & & & $\mathrm{Lt}$ & 36.5 & - & 31.4 & - & \\
\hline
\end{tabular}

women. Haque MK et al stated that midclavicular circumference is the most precise single indicator of sex, which is similar to our findings [30]. In addition, a highly significant gender-specific statistical difference was found in the midshaft circumference of the clavicle which is in consonance with studies done by all authors mentioned in (Table 3). The findings show that the clavicle's midshaft circumference has a statistically significant dimorphic relevance. There is a side-specific significant difference found in the present study for midshaft circumference in males which is in accordance with the studies done by all authors in Table 3.

When the values for midshaft circumference for right and left sides as measured for the male and females were compared they were found to be statistically significant. This could be attributable to right/left-handedness or preference of limb use by particular individuals. This correlated with Standring et al., as they observed that the mid-shaft circumference of the clavicle is the most reliable single indicator of sex, and when this is combined with weight and length it produces better results [38].

\section{CONCLUSION}

The right clavicle is longer than the left clavicle, the mean medial angle of curvature of the left clavicle is greater than the mean medial angle of curvature of the right clavicle, the average lateral angle of curvature of the left clavicle is 
greater than the average lateral angle of curvature of the right clavicle, the sum of the two angles of curvature is greater on the left than on the right side, and this variance may be attributable to ethnic, genetic, or mechanical causes. These differences should be considered by orthopedic surgeons since they may be valuable during surgical corrective treatments for clavicle fractures. Further research with large sample sizes should be conducted, and it will be most useful for forensic and anthropological professionals. The midclavicular circumference was the single most relevant variable in the direct analysis.

\section{Author contributions \& ORCID:}

All authors have agreed to take full responsibility for the content of this paper and have given their approval for its submission.

Panuganti P K - https://orcid.org/0000-0002-5260-8953

Venkateshwar R M - https://orcid.org/0000-0001-54367551

M S Poojari - https://orcid.org/0000-0001-5654-5294

Patil Shrish - https://orcid.org/0000-0002-4182-1791

J A Kumar - https://orcid.org/0000-0003-4453-9262

Competing interest: Authors state no conflict of interest.

Informed consent: Not applicable.

\section{REFERENCES}

[1]. Ýpcan MY. Forensic anthropology of sex and body size. Forensic Science International. 2005 Jan 29;147(2-3):107-12.

[2]. Góes AC, Silva DA, Domingues CS, Marreiro Sobrinho J, Carvalho EF. Identification of a criminal by DNA typing in a rape case in Rio de Janeiro, Brazil. Sao Paulo Medical Journal. 2002 May;120(3):77-9.

[3]. Ýpcan MY, Solla HE, McCabe BQ. Victim of a dictatorial regime: identification of Mr. Roberto Gomensoro Josman. Forensic science international. 2005 Jul 16;151(2-3):213-20.

[4]. Doshi MA, Reddy BB. Determination of sex of adult human clavicle by discriminant function analysis in Marathwada region of Maharashtra. International Journal of Research in Medical Sciences. 2017 Sep;5(9):3859.

[5]. Ellis H. Clinical anatomy: a revision and applied anatomy for clinical students. Annals of Surgery. 1964 Jan 1;159(1):31-5.

[6]. Olivier G. Anthropologie de la clavicule; XIII, Conclusions générales. Bulletins et Mémoires de la Société d'Anthropologie de Paris. 1956;7(5): 404-47.
[7]. Parsons FG. On the proportions and characteristics of the modern English clavicle. Journal of Anatomy. 1916 Oct;51(Pt 1):71.

[8]. Andermahr J, Jubel A, Elsner A, Johann J, Prokop A, Rehm KE, Koebke J. Anatomy of the clavicle and the intramedullary nailing of midclavicular fractures. Clinical Anatomy: The Official Journal of the American Association of Clinical Anatomists and the British Association of Clinical Anatomists. 2007 Jan;20(1):48-56.

[9]. Huang Jl, Toogood P, Chen MR, Wilber JH, Cooperman DR. Clavicular anatomy and the applicability of precontoured plates. JBJS. 2007 Oct 1;89(10):2260-5.

[10]. Terry RJ. The clavicle of the American Negro. American Journal of Physical Anthropology. 1932 Jan;16(3):351-79.

[11]. Daruwalla ZJ, Courtis P, Fitzpatrick C, Fitzpatrick D, Mullett $\mathrm{H}$. Anatomic variation of the clavicle: $\mathrm{A}$ novel three dimensional study. Clinical Anatomy: The Official Journal of the American Association of Clinical Anatomists and the British Association of Clinical Anatomists. 2010 Mar;23(2):199-209.

[12]. Walters J, Solomons M, Roche S. A morphometric study of the clavicle. SA Orthopaedic Journal. 2010 Jan;9(3):47-52.

[13]. McCormick WF, Stewart JH, Greene H. Sexing of human clavicles using length and circumference measurements. The American journal of forensic medicine and pathology. 1991 Jun 1;12(2):175-81.

[14]. Sobol J, Ptaszyñska-Sarosiek I, Charuta A, OklotaHorba M, 'aba C, Niemcunowicz-Janica A. Estimation of age at death: examination of variation in cortical bone histology within the human clavicle. Folia morphologica. 2015;74(3):378-88.

[15]. Sayee R, Janakiram S, Rajangam RK, Thomas IM. Clavicle: a metrical study. Journal of Indian Academy of Forensic Sciences. 1992;3(2):24-9.

[16]. Jit I. Sexing of adult clavicles. Ind J Med Res. 1966;54:551-71.

[17]. Sun YX, Zhao GC, Yan W. Age estimation on the female sternum by quantification theory I and stepwise regression analysis. Forensic science international. 1995 Jun 30;74(1-2):57-62.

[18]. Akhlaghi M, Moradi B, Hajibeygi M. Sex determination using anthropometric dimensions of the clavicle in Iranian population. Journal of Forensic and Legal Medicine. 2012 Oct 1;19(7):381-5.

[19]. Papaioannou VA, Kranioti EF, Joveneaux P, Nathena $D$, Michalodimitrakis M. Sexual dimorphism of the scapula and the clavicle in a contemporary Greek population: applications in forensic identification. Forensic Science International. 2012 Apr 10;217(13):231-e1.

[20]. Alcina M, Rissech C, Clavero A, Turbón D. Sexual dimorphism of the clavicle in a modern Spanish sample. Eur J Anat. 2015;19(1):73-83.

[21]. Frutos LR. Determination of sex from the clavicle and scapula in a Guatemalan contemporary rural indigenous population. The American journal of forensic medicine and pathology. 2002 Sep 1;23(3):284-8. 
[22]. Kaur K, Sidhu SS, Kaushal S, Kaur B. Sexing the northwest Indian adult clavicles of Patiala zone. J. Anat Soc India. 1997;46:121-30.

[23]. Kaur H, Harjeet SD, Jit I. Length and curves of the clavicle in Northwest Indians. J. Anat. Soc. India. 2002;51(2):199-209.

[24]. Van Dongen R. The shoulder girdle and humerus of the Australian Aborigine. American Journal of Physical Anthropology. 1963 Dec;21(4):469-88.

[25]. Singh S, Gangrade KC. The sexing of adult clavicles: Demarking points for Varanasi Zone. J. Anat. Soc. India. 1968 Aug;17:89-100.

[26]. Singh S. Sexing of American clavicles. Journal of anatomical society of India. 1969;18:25.

[27]. Jit I, Sahni D. Sexing the north Indian clavicles. J. Anat. Soc. India. 1983;32(2):61-72.

[28]. Sayee R, Janakiram S, Rajangam RK, Thomas IM. Clavicle: a metrical study. Journal of Indian Academy of Forensic Sciences. 1992;3(2):24-9.

[29]. Padeyappanavr KV, Kazi AK, Bhusreddy PS, Kulkarni UK. Sexual dimorphism in adult human clavicles of North Interior Karnataka region. J. Karnataka Med. Leg. Soc.. 2009;18(1).

[30]. Haque MK, Mansur DI, Krishnamurthy A, Karki R, Sharma K, Shakya R. Analysis of clavicle in Nepalese population. Kathmandu University Medical Journal. 2011;9(3):193-7.

[31]. Králík M, Urbanová P, Wagenknechtová M. Sex assessment using clavicle measurements: Inter-and intra-population comparisons. Forensic science international. 2014 Jan 1;234:181-e1.

[32]. Alcina M, Rissech C, Clavero A, Turbón D. Sexual dimorphism of the clavicle in a modern Spanish sample. Eur J Anat. 2015;19(1):73-83.
[33]. Ishwarkumar S, Pillay P, Haffajee MR, Rennie C. Sex determination using morphometric and morphological dimensions of the clavicle within the KwaZulu-Natal population. International Journal of Morphology. 2016 Mar 1;34(1).

[34]. Rajitha V, Anitha MR. Rekha G, Senthil Nathan S. Determination of Sex and Age from Human Clavicles and its Radiographic Images. Indian Journal of Anatomy. 20165 (1): 93-99.

[35]. Sehrawat JS, Pathak RK. Variability in anatomical features of human clavicle: Its forensic anthropological and clinical significance. Translational research in anatomy. 2016 Jun 1;3:5-14.

[36]. Shobha, Vijayakumar B Jatti, Pravinkumar NK, VasudevaMurthy.CR. Sexing of human clavicles of north Karnataka zone by measuring their mid-shaft circumference. Int J Anat Res 2019;7(1.1):61236127. DOI:10.16965/ijar.2018.420

[37]. Dehiya A, Agnihotri G, Sharma RK. Morphometric Variation of Adult Human Clavicle-A Tool for Gender Determination. International Journal of Medical and Dental Sciences. 2019 Jul 24;8(2):1793-9.

[38]. Johnson D, Ellis $H$, Standring $S$, Healy JC, Williams A, Collins P, Wigley C. Gray's anatomy: the anatomical basis of clinical practice. 2008

How to cite this article:

Praveen Kumar Panuganti, Muchintala Venkateshwar Reddy, Meghana S Poojari, Patil Shrish, Jyothi Ashok Kumar. Morphometry and Sexual Dimorphism of the Human Clavicle in South Indian Population. Int J Anat Res 2022;10(1):8283-8290. DOI: 10.16965/ijar.2021.205 